\title{
High-risk areas of leprosy in Brazil between 2001-2015
}

\author{
Áreas de alto risco de hanseníase no Brasil, período 2001-2015 \\ Áreas de alto riesgo de lepra en Brasil, en el período de 2001 a 2015
}

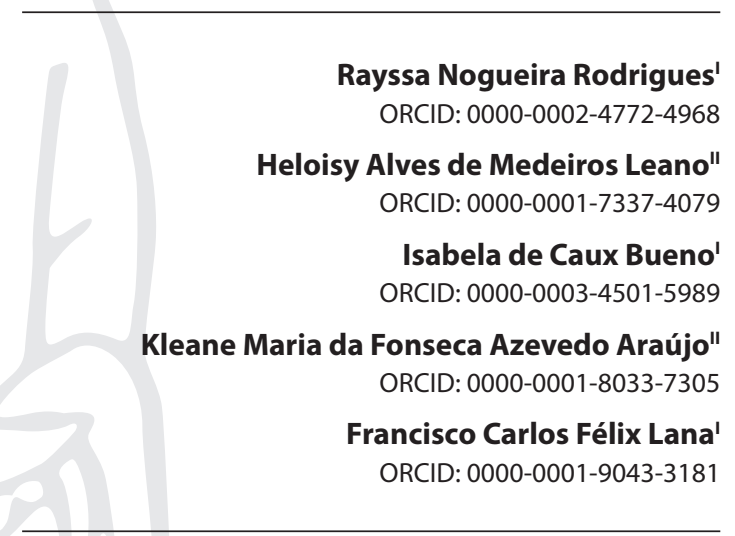

'Universidade Federal de Minas Gerais. Belo Horizonte, Minas Gerais, Brazil.

"Universidade Federal de Campina Grande. Cuité e Campina Grande, Paraíba, Brazil.

How to cite this article: Rodrigues RN, Leano HAM, Bueno IC, Araújo KMFA, Lana FCF. High-risk areas of leprosy in Brazil between 2001-2015. Rev Bras Enferm. 2020;73(3):e20180583. doi: http://dx.doi.org/10.1590/0034-7167-2018-0583

Corresponding author:

Rayssa Nogueira Rodrigues E-mail: rayssa_nr@yahoo.com.br

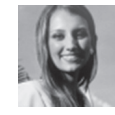

EDITOR IN CHIEF: Dulce Aparecida Barbosa ASSOCIATE EDITOR: Elucir Gir

Submission: 07-17-2018

Approval: 06-19-2019

\begin{abstract}
Objectives: to identify high-risk areas of leprosy in Brazil from 2001 to 2015. Methods: this is an ecological study of spatial analysis based on Brazilian municipalities. Spatial scan statistics were used to identify spatial clustering and measure the relative risk from the annual detection rate of new cases of leprosy. By criterion based on the Gini index, only secondary clusters were considered. Results: spatial scan statistics detected 26 clusters, in which the detection rate was 59.19 cases per 100 thousand inhabitants, while in the remainder of the country it was 11.76. Large part of the cluster area is located in the Legal Amazon. These groups included only $21.34 \%$ of the total population, but $60.40 \%$ of the new cases of the disease. Conclusions: Leprosy remains concentrated in some areas, showing the need for control programs to intensify actions in these municipalities. Descriptors: Leprosy; Endemic Diseases; Epidemiology; Cluster Analysis; Brazil.
\end{abstract}

\section{RESUMO}

Objetivos: identificar as áreas de alto risco da hanseníase no período de 2001 a 2015 no Brasil. Métodos: trata-se de um estudo ecológico de análise espacial, segundo dados dos municípios brasileiros. A estatística scan espacial foi utilizada para identificar agrupamentos espaciais e medir o risco relativo a partir do indicador taxa de detecção anual de casos novos de hanseníase. Pelo critério baseado no índice de Gini, foram considerados apenas os clusters secundários. Resultados: a estatística scan espacial detectou 26 clusters, em que a taxa de detecção foi de 59,19 casos por 100 mil habitantes, enquanto no restante do país foi de 11,76. Grande parte da área de clusters está situada na Amazônia Legal. Esses grupos incluíram apenas $21,34 \%$ da população total, mas $60,40 \%$ dos novos casos da doença do período. Conclusões: a hanseníase permanece concentrada em algumas áreas, apontando a necessidade de os programas de controle intensificarem ações nesses municípios. Descritores: Hanseníase; Doenças Endêmicas; Epidemiologia; Análise por Conglomerados; Brasil.

\section{RESUMEN}

Objetivos: identificar las áreas de alto riesgo de lepra en el período de 2001 a 2015, en Brasil. Métodos: estudio ecológico de análisis espacial, con base en los datos de los municipios brasileños. Se utilizó la estadística scan espacial para identificar las agrupaciones espaciales y medir el riesgo relativo a partir del indicador índice de detección anual de nuevos casos de lepra. Con base en el índice de Gini, se consideraron solo los clusters secundarios. Resultados: la estadística scan espacial detectó 26 clusters, en que la tasa de detección fue de 59,19 casos por 100 mil habitantes, mientras que en el resto del país fue de 11,76. La gran parte del área de clusters se encuentra en la Amazonía Legal. Estos grupos incluyeron solo el 21,34\% de la población total, pero representa el $60,40 \%$ de nuevos casos de la enfermedad en el período. Conclusiones: la lepra sigue concentrada en algunas áreas, lo que apunta la necesidad que tienen los programas de control de intensificar las acciones en estos municipios.

Descriptores: Lepra; Enfermedades Endémicas; Epidemiología; Análisis por Conglomerados; Brasil. 
High-risk areas of leprosy in Brazil between 2001-2015 Rodrigues RN, Leano HAM, Bueno IC, Araújo KMFA, Lana FCF.

\section{INTRODUCTION}

Leprosy is a severe infectious disease: more than 200 thousand new cases are reported annually, although it is curable with multidrug therapy (polychemotherapy) ${ }^{(1)}$. The last epidemiological record published by the World Health Organization (WHO) obtained data from 150 countries for 2017 and showed that Southeast Asia and the Americas are the areas most affected by the disease, with detection rates of 7.72 and 2.86 cases per 100 thousand inhabitants respectively. India, Brazil and Indonesia are the most endemic countries, accounting for $80 \%$ of the total registered cases $^{(1)}$.

Geographic variations are a striking characteristic of leprosy. Even at the national level, the occurrence is more common in certain places than in others ${ }^{(2-3)}$. Evidence indicates that the heterogeneous distribution may be associated with low income ${ }^{(4)}$ or with specific host factors, such as immunologic determinants ${ }^{(5)}$ and genetics ${ }^{(6)}$.

In some circumstances, this heterogeneous distribution may also result from the efforts of the health teams. The greater engagement in the surveillance of contacts and the examination of collectivities, for example, contributes to an increased detection. On the other hand, the absence of these actions leads to the permanence of undiagnosed cases, and as a consequence, to the continuity of the transmission chain ${ }^{(7)}$.

To better understand the differences in the spatial distribution of leprosy, studies have been conducted in Brazil; however, the scientific literature is not proportional to the intensity of the disease ${ }^{(8)}$. Of the various analytical methods used, the identification of clusters is considered a potential approach, since it does not disregard the silent areas due to a low detection effort or favors municipalities with a larger number of cases due to the size of their population and not the higher risk ${ }^{(9)}$. In addition, its use allows managers to guide the allocation of resources and public policies, giving priority to the areas where the transmission is higher ${ }^{(10)}$.

The evaluation of Brazil between 2011 and 2013 showed the presence of 10 clusters, covering 621 municipalities. They were located mainly in the states of Mato Grosso, Pará, Maranhão, Tocantins, Goiás, Rondônia and Bahia. Although they corresponded to only $14 \%$ of the Brazilian population, they accounted for $44 \%$ of the new cases diagnosed in $2013^{(11)}$.

In this scenario of geographic diversity and dynamism of the factors involved in the occurrence of leprosy, this article sought to update the data presented by the $\mathrm{WHO}^{(11)}$, incorporating a newer approach to determine non-overlapping clusters, the Gini index ${ }^{(12)}$. We chose to work with a long series of data, since the epidemiological surveillance of the disease may vary operationally from year to year, but not in a stable way, for a decade ${ }^{(13)}$.

\section{OBJETIVES}

To identify the high-risk areas (clusters) of leprosy in Brazil from 2001 to 2015.

\section{METHODS}

\section{Ethical aspects}

This study was approved by the Research Ethics Committee (COEP) of Federal University of Minas Gerais (UFMG). This study was carried out according to the determinations of Resolution no. 466, of December 12,2012 , of the National Health Council, which establishes guidelines and regulatory norms for investigations involving human beings ${ }^{(14)}$.

\section{Study design, location and period}

This is an ecological study of spatial analysis of leprosy, according to new cases diagnosed from 2001 to 2015 in Brazil. The total of 5,565 Brazilian municipalities defined by the 2010 demographic census was considered territorial units of analysis.

\section{Population and inclusion and exclusion criteria}

The study included only the new confirmed cases of leprosy, from residents in Brazil diagnosed during the study period.

\section{Study protocol}

Data regarding leprosy cases were extracted from the database tabulation of the Health Information System (Sinan) provided by the Ministry of Health through the Electronic System of Information Service for Citizen (e-SIC), and the data referring to the populations by municipalities were obtained from the inter census estimates of the Brazilian Institute of Geography and Statistics Foundation (IBGE). In a first step, these data were stored in Tab for Windows (TabWin), version 3.2. It is a computer program of public domain developed by Datasus that allows the construction and calculation of indicators.

Next, the mean rate of detection of new leprosy cases was calculated for the study period. The construction methodology was performed according to the determinations of the Ministry of Health, arranged in the Guidelines for surveillance, attention and elimination of leprosy as a public health problem ${ }^{(15)}$.

To enter the data on the map, the city code was used as geocodes. The cartographic base in digital and georeferenced format was acquired free of charge with IBGE through its website, in the area of downloads. The maps used the Universal transverse Mercator projection system (UTM), and as a geodetic reference system, the South American Datum 1969 (SAD 69).

\section{Analysis of results and statistics}

Spatial Scan Statistic was used to identify spatial clusters with higher mean detection rates of leprosy during the study period ${ }^{(16)}$. It is also known as spatial scanning statistics and allows delineating spatial clusters through a circular geographic window that moves through space with the center of coordinates of each municipal capital. The radius of the window ranged from 0 to $500 \mathrm{~km}^{(13)}$. Each cluster was tested statistically by the likelihood ratio test, and the maximum likelihood window was considered as the most probable cluster. Moreover, according to the criterion based on the Gini index, only the secondary clusters were considered, that is, those that did not overlap the most probable cluster.

The Gini index is considered a measure of statistical dispersion, being an alternative and newer approach "able to determine when it makes more sense to report a collection of smaller clusters without overlap than a single large cluster containing all of them ${ }^{\prime \prime(12, p .27)}$. SaTScan selects the non-overlapping cluster group 
that maximizes the Gini index, so there is a large difference in rates between clustered and non-clustered areas, allowing thus the identification of a more refined collection of non-overlapping clusters.

Finally, estimates for the relative risk were calculated. This measure allows to compare information from different areas, standardizing them and removing the effect from populations. Whether it is a geographic region formed by clusters denoted by $C_{1}, C_{2}, C_{3} \ldots, C_{k}$. Whether $X$ is a variable that indicates the number of leprosy cases, so each occurrence of $X_{i}(i=1,2,3 \ldots, k)$ is associated with the cluster, with population $n_{i}(i=1,2,3 \ldots, k)$. The relative risk of a cluster $C_{i}$ is the quotient between the leprosy detection rate observed in the cluster $C_{i}$ and the detection rate of the other regions of study.

The SaTScan software (version 9.6) was used to make the maps and perform the analyses.

\section{RESULTS}

From 2001 to $2015,605,673$ new cases of leprosy were reported in Brazil, and, of these, 605,651 could be georeferenced, which is equivalent to an average detection rate of 21.65 cases per each 100 thousand inhabitants. The spatial scan statistic detected the presence of 26 statistically significant and secondary clusters, that is, they did not overlap the other clusters (Figure 1), totaling 1,350 Brazilian municipalities, located mainly in the states of Goiás ( $\mathrm{n}=$ $175,12.96 \%)$, Piauí $(n=171,12.67 \%)$, Maranhão $(n=157,11.63 \%)$ and Mato Grosso ( $n=130,9.63 \%)$.

Although present in a large geographic area of the Legal Amazon, the clusters identified were found in locations with low demographic densities. They accounted for only $21.34 \%$ of the Brazilian population, but $60.40 \%(n=365,836)$ of the new leprosy cases reported during the study period.

Among the municipalities that formed the cluster, four presented the mean rate of leprosy equal to zero, they are: Ribeirão dos Índios-SP, Bela Vista do Piauí-PI, Monte Formoso-MG and Caridade do Piauí-PI.

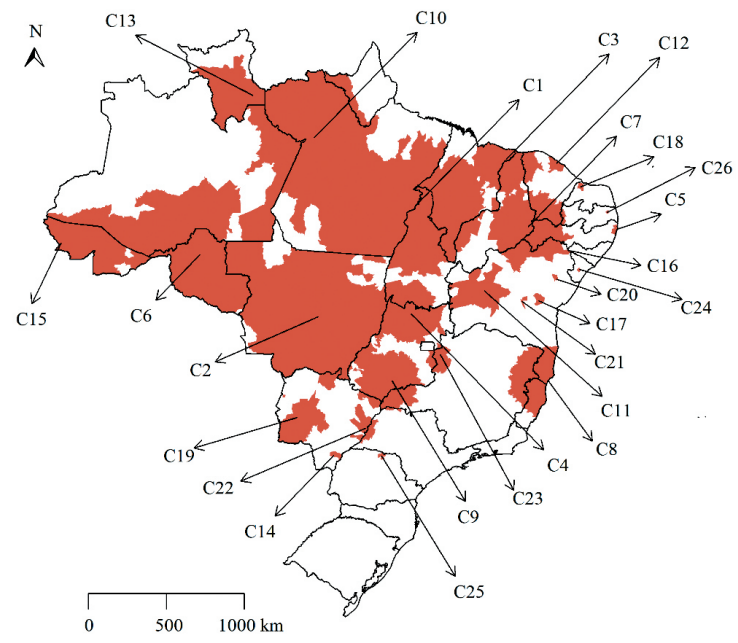

Figure 1 - High-risk clusters of leprosy, Brazil from 2001 to 2015
Based on the study by Penna and collaborators ${ }^{(13)}$, Tables 1 and 2 show the characteristics of the clusters identified. We observed that the areas with the highest relative risks (above 3) were concentrated in the midwest, north and northeast regions, totaling 473 (35\%) municipalities (Table 1 and Figure 2).

Table 1 - Data on high-risk clusters of leprosy, Brazil from 2001 to 2015

\begin{tabular}{|c|c|c|c|c|}
\hline Clusters & Central municipality-FU & $\begin{array}{l}\text { Radius } \\
(\mathbf{k m})\end{array}$ & $\begin{array}{c}\text { Number of } \\
\text { municipalities }\end{array}$ & $\begin{array}{c}\text { Relative } \\
\text { risk* }\end{array}$ \\
\hline 1 & São Geraldo do Araguaia-PA & 498.2 & 259 & 5.2 \\
\hline 2 & Santa Rita do Trivelato-MT & 497.1 & 140 & 5.3 \\
\hline 3 & São Bernardo-MA & 244.5 & 147 & 2.6 \\
\hline 4 & Formoso-GO & 218.6 & 71 & 4.9 \\
\hline 5 & Olinda-PE & 36.7 & 13 & 2.5 \\
\hline 6 & Alto Paraíso-RO & 492.4 & 68 & 2.9 \\
\hline 7 & Curral Novo do Piauí-PI & 278.4 & 208 & 2.4 \\
\hline 8 & Mucuri-BA & 274.6 & 138 & 2.2 \\
\hline 9 & Castelândia-GO & 219.3 & 132 & 2.2 \\
\hline 10 & Óbidos-PA & 441.5 & 39 & 2.1 \\
\hline 11 & Wanderley-BA & 141.3 & 24 & 2.7 \\
\hline 12 & São Gonçalo do Amarante-CE & 63.9 & 19 & 1.5 \\
\hline 13 & Caroebe-RR & 241.0 & 9 & 2.5 \\
\hline 14 & Naviraí-MS & 0.0 & 1 & 5.6 \\
\hline 15 & Marechal Thaumaturgo-AC & 498.7 & 17 & 2.2 \\
\hline 16 & Paulo Afonso-BA & 0.0 & 1 & 3.0 \\
\hline 17 & laçu-BA & 28.5 & 2 & 2.9 \\
\hline 18 & Mossoró-RN & 0.0 & 1 & 2.1 \\
\hline 19 & Bodoquena-MS & 196.3 & 16 & 1.9 \\
\hline 20 & Araci-BA & 0.0 & 1 & 3.6 \\
\hline 21 & Andaraí-BA & 0.0 & 1 & 6.4 \\
\hline 22 & Brasilândia-MS & 79.1 & 21 & 1.7 \\
\hline 23 & Unaí-MG & 96.1 & 8 & 1.9 \\
\hline 24 & Itabaiana-SE & 9.1 & 2 & 2.4 \\
\hline 25 & Rancho Alegre-PR & 21.6 & 6 & 2.7 \\
\hline 26 & Cuitegi-PB & 12.8 & 6 & 2.2 \\
\hline
\end{tabular}

Note: *Relative risk has been stratified according to its quartiles.

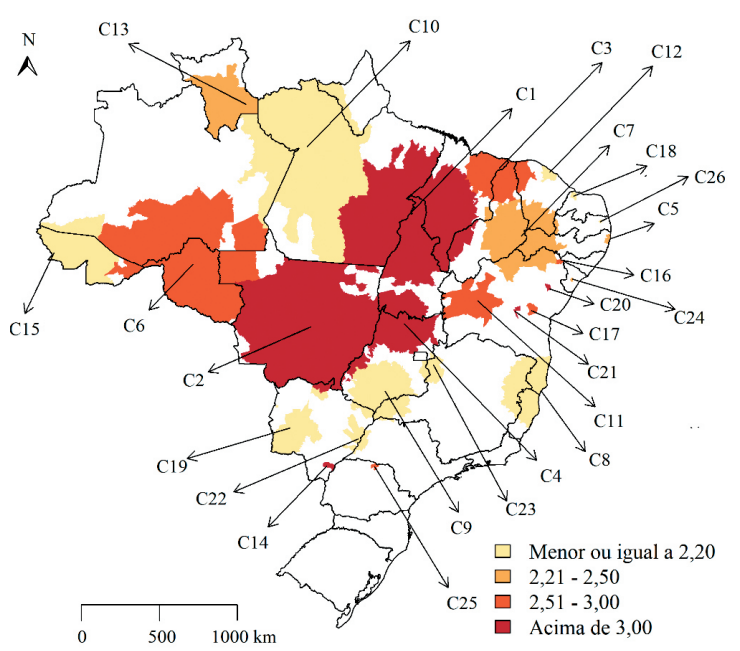

Figure 2 - Relative risk of clusters, Brazil from 2001 to 2015 
In the cluster areas, the mean detection rate of leprosy cases in the period was 59.19 per 100 thousand inhabitants, while in the remainder of the country it was 11.76 per 100 inhabitants, rate ratio of 5.03. Rio Grande do Norte was the state that presented the highest rate ratios (6.43), followed by the states of Bahia (4.96) and Minas Gerais (4.88). Paradoxically, in the states of Amapá (0.99) and Piauí (0.94), the greatest risks to contract the disease were located in areas outside the clusters (Table 2 ).

Table 2 - Rate ratios of the municipalities included and not included in high-risk clusters, population and cases in clusters according to the federative unit (FU), Brazil from 2001 to 2015

\begin{tabular}{|c|c|c|c|c|c|}
\hline \multirow{2}{*}{ FU } & \multicolumn{2}{|c|}{$\begin{array}{l}\text { Detection rate per } 100 \\
\text { thousand inhabitants }\end{array}$} & \multirow{2}{*}{$\begin{array}{l}\text { Rate } \\
\text { Ratios }\end{array}$} & \multirow{2}{*}{$\begin{array}{c}\text { Population } \\
\text { in cluster } \\
(\%)\end{array}$} & \multirow{2}{*}{$\begin{array}{c}\text { Cases } \\
\text { in cluster } \\
(\%)\end{array}$} \\
\hline & $\begin{array}{l}\text { Outside the } \\
\text { cluster }\end{array}$ & $\begin{array}{l}\text { In } \\
\text { cluster }\end{array}$ & & & \\
\hline AC & 43.93 & 48.45 & 1.10 & 94.67 & 94.17 \\
\hline $\mathrm{AL}$ & 9.90 & - & - & - & - \\
\hline$A M$ & 24.29 & 37.90 & 1.56 & 20.30 & 31.73 \\
\hline AP & 22.25 & 22.13 & 0.99 & 7.91 & 7.60 \\
\hline BA & 10.07 & 49.92 & 4.96 & 14.68 & 46.22 \\
\hline CE & 15.66 & 29.16 & 1.86 & 71.66 & 83.09 \\
\hline DF & 10.68 & - & - & - & - \\
\hline ES & 15.11 & 49.21 & 3.26 & 74.77 & 87.97 \\
\hline GO & 38.28 & 63.90 & 1.67 & 67.27 & 80.00 \\
\hline MA & 42.76 & 60.34 & 1.41 & 82.44 & 88.98 \\
\hline MG & 8.25 & 40.25 & 4.88 & 8.45 & 34.02 \\
\hline MS & 27.27 & 56.42 & 2.07 & 24.63 & 44.57 \\
\hline MT & 109.82 & 111.73 & 1.02 & 96.15 & 96.27 \\
\hline PA & 33.45 & 97.74 & 2.92 & 44.38 & 67.16 \\
\hline PB & 12.20 & 36.77 & 3.01 & 6.32 & 16.63 \\
\hline PE & 14.11 & 40.31 & 2.86 & 52.48 & 78.09 \\
\hline $\mathrm{PI}$ & 31.56 & 29.76 & 0.94 & 87.60 & 91.07 \\
\hline PR & 16.26 & 60.85 & 3.74 & 0.51 & 2.45 \\
\hline RJ & 13.07 & - & - & - & - \\
\hline RN & 6.97 & 44.76 & 6.43 & 7.93 & 36.08 \\
\hline RO & 17.73 & 74.36 & 4.19 & 99.56 & 99.89 \\
\hline $\mathrm{RR}$ & 19.22 & 71.75 & 3.73 & 85.41 & 94.12 \\
\hline RS & 1.98 & - & - & - & - \\
\hline SC & 3.18 & - & - & - & - \\
\hline SE & 16.92 & 55.73 & 3.29 & 5.07 & 11.18 \\
\hline SP & 8.82 & 24.90 & 2.82 & 0.76 & 5.19 \\
\hline TO & 66.78 & 77.74 & 1.16 & 89.68 & 92.86 \\
\hline Brazil & 11.76 & 59.19 & 5.03 & 21.63 & 60.40 \\
\hline
\end{tabular}

It is also noteworthy the states of Rondônia, Mato Grosso and Acre, whose percentages of population included in clusters were the largest in Brazil. On the other hand, for some states, there is no information presented. This is a result of the absence of municipalities included in the clusters.

\section{DISCUSSION}

For 27 years, Brazil has proposed the elimination of leprosy as a public health problem ${ }^{(17)}$, but the data presented in this study reveal that the measures adopted have not had the expected effect. The detection rate of new cases of the disease is still high. According to the parameters of the Ministry of Health, the country is classified as an area of very high endemicity ${ }^{(15)}$.

The distribution of the disease is heterogeneous, and the highest values of the detection rate are found in the north, midwest and northeast regions. Large part of the cluster area is located in the Legal Amazon. This comprises an area of approximately 5 million $\mathrm{km}^{2}$ and encompasses the states of Acre, Amapá, Amazonas, Pará, Rondônia, Roraima, Tocantins, Mato Grosso, besides part of Maranhão(18).

Although the rate of leprosy detection has decreased recently, promoted by WHO goals and joint actions of the most affected countries ${ }^{(19)}$, the uncertainties regarding the factors underlying its persistence remain in certain regions. The clusters, identified in this study, resemble those established based on the data from 2005 to $2007^{(3)}, 2007$ to $2009^{(13)}$ and 2011 to $2013^{(11)}$.

A study conducted in 2010 indicated that the occurrence of leprosy in the Legal Amazon is associated with the indicators of living conditions and the mode of territorial occupation ${ }^{(20)}$. Credit policies have caused a growing influx of people to that region in the $1970 \mathrm{~s}^{(21)}$. Although this process has been strongly encouraged by the Brazilian government, it has brought side effects ${ }^{(21)}$ due to the overload/absence of the existing infrastructure.

In Pará, the regions with the highest relative risks are in the southeast and center-south of the state. The increased occurrence of the disease in these regions is believed to be associated with the construction of BR-153 (Belém-Brasília Highway), initiated in the 1970s and considered an important breakthrough for the expansion of the agricultural frontier in $\mathrm{Brazi}^{(22)}$.

The endemicity of leprosy in the state of Tocantins can also be a reflection of urbanization and migration, potentialized after the construction of BR-153 ${ }^{(23)}$. Similarly, the opening of federal and state highways in Mato Grosso facilitated territorial occupation and consequently the occurrence of leprosy in the state ${ }^{(24)}$.

Therefore, migration explains the installation of leprosy, but its maintenance may be associated with other factors, such as greater environmental or even individual vulnerability ${ }^{(24)}$. This occurs because many regions that are losing population do not record falls in detection rates. On the contrary, they remain high or, in some cases, a progressive increase is observed ${ }^{(24)}$.

According to IBGE data, the midwest and north regions have the lowest estimates of the population residing in Brazil ${ }^{(25)}$. However, many states have more than half of their populations included in clusters, with higher rate ratios in those locations.

These data are alarming, since it has been shown that, in addition to home contacts, people close to the leprosy case, such as social contacts, present risks of infection, being inversely decreasing with the increase in distance ${ }^{(26)}$. Thus, the administration of polychemotherapy to all newly detected patients should be associated with rigorous surveillance of their contacts.

Immunoprophylaxis with Bacillus Calmette-Guérin (BCG) is considered an effective preventive measure in the control of the disease due to its ability to stimulate the development of cellular Immunity ${ }^{(27)}$. The Ministry of Health recommends that BCG be administered in contacts without the presence of signs and symptoms of leprosy and respecting the criteria of vaccination history ${ }^{(15)}$. More recently, it has been shown that chemoprophylaxis in a single dose of rifampicin also consists of a promising measure to prevent the disease ${ }^{(27)}$.

If leprosy has been highly endemic for more than 100 years in the Amazon region, on the other hand, in the northeastern region of Brazil, its occurrence has been rare. Only in 1985 the 
High-risk areas of leprosy in Brazil between 2001-2015 Rodrigues RN, Leano HAM, Bueno IC, Araújo KMFA, Lana FCF.

Ministry of Health found the expansion of the endemic disease in the country and identified the northeast as the region that presented the highest annual growth rates ${ }^{(28)}$.

It is noteworthy that the relative risks of detection (2.51) of the northeast were located in part of Maranhão, Piauí, Ceará and Bahia. Although, in Maranhão, large area corresponds to an extension of the Legal Amazon.

There is still evidence of the tendency to maintain leprosy in these northeastern states, because there is no significant decrease in important surveillance indicators, such as the proportion of degree 2 of physical disability at the time of diagnosis and the detection rate under 15 years ${ }^{(29)}$.

Often, the disease is related to indicators of poverty, such as low income and schooling ${ }^{(30)}$. The northeast region, among the less developed regions, stands out in this scenario. Paradoxically, the southeast and south regions are located in the favorable extreme of the country, although Espírito Santo, Minas Gerais, São Paulo and Paraná present municipalities belonging to the clusters.

The relationship of the disease with poverty is unquestionable; however, it does not mean that all places under these conditions are endemic. The expansion of population coverage estimated by Family Health Strategy $(\mathrm{FHS})^{(7)}$, as well as the presence of health professionals trained and committed to the actions of disease control facilitates the diagnosis of leprosy ${ }^{(31)}$ and, consequently, increases the detection rate.

The state of São Paulo, for example, occupies the third position among those with the lowest detection rate of new cases in Brazil. But an investigation conducted in Jardinópolis, a city located in the northern end of the state, identified 24 new cases of leprosy from July to December 2015. In the previous period, from 2005 to 2014 , Jardinópolis had registered only 11 cases. This growth made the municipality increase the average rate of 2.62 per 100 thousand inhabitants to 42.8 in $2015^{(32)}$. Thus, areas supposedly classified as low endemicity may have occult cases of leprosy.

In addition, municipalities with very high rates are usually neighbors of others with high or intermediate rates as well. Therefore, the situation is more alarming when it comes to silent municipalities, which do not notify any case of the disease, even when they are inserted in an endemic region. In the case of Monte Formoso-MG, the situation had already been reported in the period from 1998 to $2006^{(33)}$.

The graphic representation also highlights the need for managers, from different spheres, to share their responsibilities, because the clusters identified do not coincide with the areas of action of the state governments.

\section{Limitations of the study}

Among the limitations of this study, it is noteworthy that the use of secondary data can often present inconsistencies and non-completeness, but, despite this, the choice for this type of source reduces operating costs and does not preclude the analysis.

Finally, the power of discrimination can be considered low in states where the relative risk was close to 1 .

\section{Contributions to the field of nursing, health or public policy}

This study intends to help managers and health professionals strengthen the actions of epidemiological surveillance of leprosy and organize the Health Care Network (HCN). To do so, it is necessary to ensure the training of health professionals in a continuous way so the skills and knowledge are sustained, especially in primary health care $(\mathrm{PHC})$, as the decentralization of leprosy control actions for $\mathrm{PHC}$ is advocated by the Ministry of Health since the implementation of the teams of Community Health Agents (1991) and the Family Health Program (FHP) (1994).

\section{CONCLUSIONS}

The study of the spatial distribution of leprosy provided information that would not be visualized working only with tabular data. The high-risk clusters estimated by the scan statistic showed the focal and unequal behavior among the regions of Brazil, indicating the priority areas of intervention. Furthermore, the support of the epidemiological framework requires new research approaches to improve the understanding of factors that condition or even determine the maintenance of the disease in certain regions of the country.

\section{REFERENCES}

1. World Health Organization (WHO). Global leprosy update, 2017: reducing the disease burden due to leprosy. Wkly Epidemiol Rec [Internet]. 2018 [cited 2018 Sept 10];93(35):445-56. Available from: https://apps.who.int/iris/bitstream/handle/10665/274290/WER9335-445-456. pdf?sequence=1\&isAllowed $=y$

2. Brook CE, Beauclair R, Ngwenya O, Worden L, Ndeffo-Mbah M, Lietman TM, et al. Spatial heterogeneity in projected leprosy trends in India. Parasit Vectors. 2015;8:542-52. doi: 10.1186/s13071-015-1124-7

3. Penna MLF, Wand-Del-Rey-de-Oliveira ML, Penna G. Spatial distribution of leprosy in the Amazon region of Brazil. Emerg Infect Dis. 2009;15(4):650-2. doi: 10.3201/eid1504.081378

4. Nery JS, Pereira SM, Rasella D, Penna MLF, Aquino R, Rodrigues LC, et al. Effect of the Brazilian Conditional Cash Transfer and Primary Health Care Programs on the New Case Detection Rate of Leprosy. PLoS Negl Trop Dis. 2014;8(11):e3357. doi: 10.1371/journal.pntd.0003357

5. Masaki T, McGlinchey A, Cholewa-Waclaw J, Qu J, Tomlinson SR, Rambukkana A. Innate Immune Response Precedes Mycobacterium LepraeInduced Reprogramming of Adult Schwann Cells. Cell Reprogram. 2014;16(1):9-17. doi: 10.1089/cell.2013.0064

6. Benjak A, Avanzi C, Singh P, Loiseau C, Girma S, Busso P, et al. Phylogenomics and Antimicrobial Resistance of the Leprosy Bacillus Mycobacterium Leprae. Nat Commun. 2018;9(1):352-62. doi: 10.1038/s41467-017-02576-z 
High-risk areas of leprosy in Brazil between 2001-2015 Rodrigues RN, Leano HAM, Bueno IC, Araújo KMFA, Lana FCF.

7. Gomes FBFF, Lana FCF, Oliveira RC, Rodrigues RN. Indicators of Leprosy in the State of Minas Gerais and its Relationship With the Municipal Human Development Index and the Coverage of the Family Health Strategy. Rev Min Enferm [Internet]. 2017 [cited 2018 Jun 10];21:e-1063. Available from: http://www.reme.org.br/artigo/detalhes/1201

8. Silva CLM, Fonseca SC, Kawa H, Palmer DOQ. Spatial distribution of leprosy in Brazil: a literature review. Rev Soc Bras Med Trop. 2017;50(4):439-49. doi: 10.1590/0037-8682-0170-2016

9. Brasil. Ministério da Saúde. Secretaria de Vigilância em Saúde. Vigilância em Saúde: situação epidemiológica da hanseníase no Brasil. Brasília: Ministério da Saúde; 2008. 12 p.

10. Ramos ACV, Yamamura M, Arroyo LH, Popolin MP, Chiaravalloti Neto F, Palha PF, et al. Spatial Clustering and Local Risk of Leprosy in São Paulo, Brazil. PLoS NegI Trop Dis. 2017;11(2):e0005381. doi: 10.1371/journal.pntd.0005381

11. World Health Organization (WHO). Cluster Analysis of the Overall Detection Rate of Leprosy in Brazil for the Triennium 2011-2013. Leprosy elimination [Internet]. Geneva:WHO; 2015 [cited 2018 Apr 26]. Available from: http://www.who.int/lep/news/Cluster_analysis/en/

12. Han J, Zhu L, Kulldorff M, Hostovich S, Stinchcomb DG, Tatalovich Z, et al. Using Gini Coefficient to Determining Optimal Cluster Reporting Sizes for Spatial Scan Statistics. Int J Health Geogr. 2016;15(1):27-37. doi: 10.1186/s12942-016-0056-6

13. Penna MLF, Grossi MAF, Rocha MCN, Penna GO. Comportamento epidemiológico da hanseníase no Brasil. In: Brasil. Ministério da Saúde. Secretaria de Vigilância em Saúde. Saúde Brasil 2009: uma análise da situação de saúde e da agenda nacional e internacional de prioridades em saúde [Internet]. Brasília: Ministério da Saúde; 2010 [cited 2018 Jun 10]. 368 p. Available from: http://bvsms.saude.gov.br/bvs/ publicacoes/saude_brasil_2009.pdf

14. Ministério da Saúde (BR). Conselho Nacional de Saúde. Comissão Nacional de Ética em Pesquisa. Resolução no 466 , de 12 de dezembro de 2012. Diário Oficial da União [Internet]. 2013 June 13 [cited 2018 June 10];1:59. Available from: http://conselho.saude.gov.br/ resolucoes/2012/Reso466.pdf

15. Ministério da Saúde (BR). Secretaria de Vigilância em Saúde. Diretrizes para vigilância, atenção e eliminação da hanseníase como problema de saúde pública: manual técnico-operacional [Internet]. Brasília: Ministério da Saúde; 2016 [cited 2018 Jun 10]. 60 p. Available from: http://portal. saude.pe.gov.br/sites/portal.saude.pe.gov.br/files/diretrizes_para_.eliminacao_hanseniase_-_manual_-_3fev16_isbn_nucom_final_2.pdf

16. Kulldorff M. A Spatial Scan Statistic. Commun Stat Theory Methods. 1997;26(6):1481-96. doi: 10.1080/03610929708831995

17. World Health Assembly. Leprosy resolution WHA44.9 [Internet]. Geneva: World Health Organization. 1991 [cited 2018 June 10 ]. Available from: http://www.who.int/neglected_diseases/mediacentre/WHA_44.9_Eng.pdf

18. Instituto Brasileiro de Geografia e Estatística. Áreas Especiais: Cadastro de Municípios localizados na Amazônia Legal. Rio de Janeiro: IBGE; 2014 [cited 2018 Apr 25]. Available from: https://ww2.ibge.gov.br/home/geociencias/geografia/amazonialegal.shtm?c=2

19. World Health Organization (WHO). Global Leprosy Strategy 2016-2020: accelerating towards a leprosy-free world. Geneva: WHO; 2016 [cited 2018 Jun 10], 21 p. Available from: http://apps.who.int/iris/bitstream/handle/10665/208824/9789290225096_en.pdf?sequence=14\&isAllowed=y

20. Silva DRX, Ignotti E, Souza-Santos R, Hacon SS. Hanseníase, condições sociais e desmatamento na Amazônia brasileira. Rev Panam Salud Publica [Internet]. 2010 [cited 2018 Jun 10];27(4):268-75. Available from: https://scielosp.org/pdf/rpsp/2010.v27n4/268-275/pt

21. Andersen LE, Reis EJ. Deforestation, development, and government policy in the brazilian amazon: an econometric analysis [Internet]. Rio de Janeiro: Ipea. 1997 [cited 2018 Jun 10]. Available from: http://ipea.gov.br/agencia/images/stories/PDFs/TDs/ingles/dp_69.pdf

22. Magalhães MCC, Rojas LI. Spatial Differentiation of Leprosy in Brazil. Epidemiol Serv Saúde [Internet]. 2007 [cited 2018 Jun 10];16(2):75-84. Available from: http://scielo.iec.gov.br/pdf/ess/v16n2/v16n2a02.pdf

23. Monteiro LD, Martins-Melo FR, Brito AL, Alencar CH, Heukelbach J. Spatial patterns of leprosy in a hyperendemic state in Northern Brazil, 2001-2012. Rev Saúde Pública. 2015;49:84-91. doi: 10.1590/S0034-8910.2015049005866

24. Magalhães MCC, Santos ES, Queiroz ML, Lima ML, Borges RCM, Souza MS, et al. Migration and Hansen's disease in Mato Grosso. Rev Bras Epidemiol. 2011;14(3):386-97. doi: 10.1590/S1415-790X2011000300004

25. Instituto Brasileiro de Geografia e Estatística. Estimativas de população para $1^{\circ}$ de julho de 2016 [Internet]. 2017 [cited 2018 Apr 25 ]. Available from: ftp://ftp.ibge.gov.br/Estimativas_de_Populacao/Estimativas_2016/estimativa_TCU_2016_20170614.pdf

26. Feenstra SG, Nahar Q, Pahan D, Oskam L, Richardus JH. Social contact patterns and leprosy disease: a case-control study in Bangladesh. Epidemiol Infect.2013;141(3):573-81. doi: 10.1017/S0950268812000969

27. Santos DS, Duppre NC, Sarno EN, Pinheiro RO, Sales AM, Nery JAC, et al. Chemoprophylaxis of leprosy with rifampicin in contacts of multibacillary patients: study protocol for a randomized controlled trial. Trials. 2018;19(1):244-53. doi: 10.1186/s13063-018-2623-6

28. Ministério da Saúde (BR). Secretaria Nacional de Programas Especiais de Saúde. Diretrizes do Programa de Controle da Hanseníase, 19861990. Brasília: Ministério da Saúde; 1986.

29. Leano HAM, Araújo KMFA, Rodrigues RN, Bueno IC, Lana FCF. Indicators related to physical disability and diagnosis of leprosy. Rev Rene. 2017;18(6):832-9. doi: 10.15253/2175-6783.2017000600018

30. Assis IS, Arcoverde MAM, Ramos ACV, Alves LS, Berra TZ, Arroyo LH, et al. Social determinants, their relationship with leprosy risk and temporal trends in a tri-border region in Latin America. PLoS NegI Trop Dis. 2018;12(4):e0006407. doi: 10.1371/journal.pntd.0006407

31. Abeje T, Negera E, Kebede E, Hailu T, Hassen I, Lema T, et al. Performance of general health workers in leprosy control activities at public health facilities in Amhara and Oromia States, Ethiopia. BMC Health Serv Res. 2016;16:122-8. doi: 10.1186/s12913-016-1329-2 
32. Bernardes-Filho F, Paula NA, Leite MN, Abi-Rached TLC, Vernal S, Silva MB, et al. Evidence of hidden leprosy in a supposedly low endemic area of Brazil. Mem Inst Oswaldo Cruz. 2017;112(12):822-8. doi: 10.1590/0074-02760170173

33. Amaral EP, Lana FCF. Spacial analysis of Leprosy in the microregion of Almenara, MG, Brazil. Rev Bras Enferm. 2008;61 (esp): 701-7. doi: $10.1590 /$ S0034-71672008000700008 